Methods: Observational, multicenter study of 312 patients with GCA treated with TCZ. Patients were diagnosed with GCA accordingly to a) ACR criteria, and/or b) biopsy of temporal artery, and/or c) presence of LVV by imaging.

Patients were divided into two subgroups: a) with, and b) without visual involvement at any time. Visual manifestations were classified as: a) Transient visual loss (TVL) (amaurosis fugax), b) Permanent visual loss (PVL) (longer than 24 hours) (partial or complete; unilateral or bilateral), c) diplopia, and d) blurred vision. Accordingly to visual duration up to TCZ onset, we considered: a) 1-10 days, b) 11-30 days, and c) more than 30 days.

Results: We studied 312 (218 women/94 men; mean age73.4+9.6 years) Visual manifestations at any time (before and/or after TCZ) were observed in $78(25 \%)$. In 47 of them visual manifestations were present at TCZ onset, and in the remaining 31 patients had had a complete recovery. Main clinical features of GCA with and without visual involvement are shown in TABLE. Patients with visual involvement were older, with other ischemic complications, and requiring more corticosteroids dose.

Table 1. Main features of $\mathbf{3 1 2}$ patients at TCZ onset.

\begin{tabular}{|c|c|c|c|c|}
\hline & $\begin{array}{l}\text { Overall } \\
\mathrm{N}=312\end{array}$ & $\begin{array}{l}\text { GCA with visual } \\
\text { involvement } \\
(n=78)\end{array}$ & $\begin{array}{l}\text { GCA without } \\
\text { visual } \\
\text { involvement } \\
(n=234)\end{array}$ & $\mathbf{p}$ \\
\hline \multicolumn{5}{|l|}{ General features } \\
\hline Age $($ mean $\pm S D)$ & $73.4 \pm 9.6$ & $76.6 \pm 8.0$ & $72.4 \pm 9.8$ & $0.001^{*}$ \\
\hline Female/Male(\% of female), $\mathrm{n}$ & 218/94 (70) & 47/31 (60) & 171/63(73) & $0.046^{\star}$ \\
\hline $\begin{array}{l}\text { Time from GCA diagnosis to TCZ } \\
\text { onset (months), median [IQR] }\end{array}$ & $8[3-24]$ & $5[1-14]$ & $10[3-24]$ & $0.040^{*}$ \\
\hline $\begin{array}{l}\text { Positive TAB, } \mathbf{n}(\%) \\
\text { Ischemic manifestations }\end{array}$ & $137 / 229(60)$ & $33 / 60(55)$ & $104 / 169(61)$ & 0.444 \\
\hline Visual involvement, n (\%) & $47(15)$ & $47(60)$ & 0 & $0.000^{*}$ \\
\hline Headache, n (\%) & $166(53)$ & $59(76)$ & $107(46)$ & $0.000^{\star}$ \\
\hline Jaw claudication & $60(19)$ & $26(33)$ & $34(14)$ & $0.001^{*}$ \\
\hline \multicolumn{5}{|l|}{ Systemic manifestations } \\
\hline Fever, $\mathrm{n}(\%)$ & $27(9)$ & $8(10)$ & $19(8)$ & 0.743 \\
\hline Constitutional syndrome, n (\%) & $115(37)$ & $30(38)$ & $85(36)$ & 0.878 \\
\hline PmR, n (\%) & $188(60)$ & $46(59)$ & $142(61)$ & 0.830 \\
\hline \multicolumn{5}{|l|}{ Acute phase reactants } \\
\hline ESR, mm/1st hour, median [IQR] & $27[10-50]$ & $34.5[15.2-58]$ & $26.0[10.0-48.0]$ & 0.193 \\
\hline CRP (mg/dL), median [IQR] & 1.4 [0.4-3.3] & $1.5[0.3-5.5]$ & $1.3[0.4-2.9]$ & 0.134 \\
\hline $\begin{array}{l}\text { Prednisone dose, mg/day, } \\
\text { mean } \pm \text { SD }\end{array}$ & $22.3 \pm 16.6$ & $27.1 \pm 18.6$ & $20.8 \pm 15.6$ & $0.008^{*}$ \\
\hline TCZmono/TCZcombo, n (\%) & $211 / 101$ & $57 / 21$ & $154 / 80$ & 0.295 \\
\hline Follow-up (months), mean $\pm S D$ & $28.4 \pm 21.8$ & $25.8 \pm 22.4$ & $29.3 \pm 21.6$ & 0.119 \\
\hline
\end{tabular}

After TCZ onset, none patient developed new visual involvement. At TCZ onset 47 patients had the following visual manifestations; PVL $(n=28$; unilateral/bilateral; 22/6), TVL ( $n=15$; unilateral/bilateral; 9/6), diplopia $(n=2)$ and blurred vision $(n=2)$.

None of the patients with TVL presented new episodes after TCZ onset, while 8 out of 28 patients with PVL experienced partial improvement (FIGURE). The 2 patients with diplopia and 1 of 2 patients with blurred vision improved.

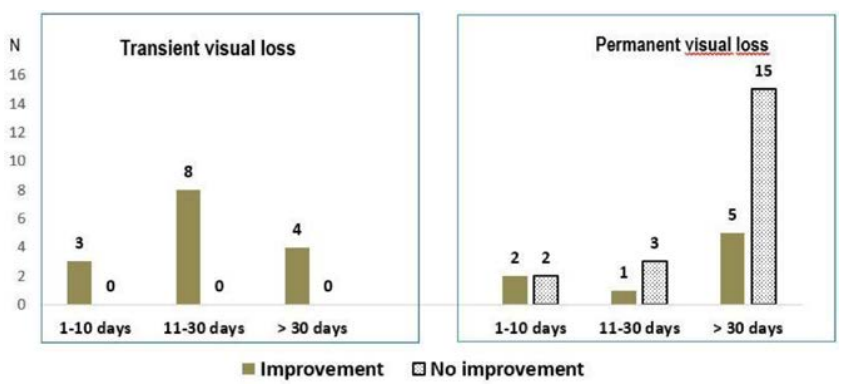

Figure 1. Efficacy of TCZ in 47 patients with GCA and visual involvement at TCZ onset.

Conclusion: TCZ seems to prevent the appearance of new ocular manifestations. When they are present, TCZ may improve totally TVL and partially PVL. REFERENCES:

[1] Stone JH, et al. N Engl J Med. 2017; 377: 317-28.

[2] Calderón-Goercke M, et al. Semin Arthritis Rheum 2019;49:126-35. https:// doi.org/10.1016/j.semarthrit.2019.01.003.

[3] Prieto Peña D et al. Clin Exp Rheumatol 2020 Nov 27. PMID: 33253103.

[4] Loricera J, et al. Clin Exp Rheumatol 2016; 34:S44-53. PMID: 27050507.

Disclosure of Interests: Lara Sanchez-Bilbao: None declared, Javier Loricera: None declared, Vicente Aldasoro: None declared, Rafael Melero: None declared, Santos Castañeda: None declared, Olga Maiz: None declared, Clara Moriano:
None declared, Ignacio Villa-Blanco: None declared, Eztizen Labrador-Sánchez: None declared, Cristina Hidalgo: None declared, Sara Manrique Arija: None declared, Eva Galíndez-Agirregoikoa: None declared, Eva Perez-Pampín: None declared, Andrea García-Valle: None declared, Cristina Campos Fernández: None declared, Juan Ramón De Dios: None declared, Carlota Laura Iñíguez: None declared, José Luis Andréu Sánchez: None declared, Julio Sánchez: None declared, Monica Calderón-Goercke: None declared, Miguel A González-Gay Speakers bureau: Abbvie, Pfizer, Roche, Sanofi, Lilly, Celgene and MSD, Consultant of: Abbvie, Pfizer, Roche, Sanofi, Lilly, Celgene and MSD, Grant/research support from: Abbvie, MSD, Jansen and Roche, Ricardo Blanco Speakers bureau: Abbvie, Lilly, Pfizer, Roche, Bristol-Myers, Janssen, UCB Pharma and MSD, Consultant of: Abbvie, Lilly, Pfizer, Roche, Bristol-Myers, Janssen, UCB Pharma and MSD, Grant/research support from: Abbvie, MSD and Roche DOI: 10.1136/annrheumdis-2021-eular.2169

\section{OP0066 METABOLIC PROFILE AND COMORBIDITIES IN GIANT CELL ARTERITIS AND POLYMYALGIA RHEUMATICA PATIENTS BEFORE AND AFTER TREATMENT}

I. Esen ${ }^{1,2}$, P. Therkildsen ${ }^{3}$, B. Dalsgaard Nielsen ${ }^{4}$, A. Van 't Ende' ${ }^{1}$ A. Boots ${ }^{1,2}$, P. Heeringa ${ }^{2,5}$, E. M. Hauge ${ }^{4}$, E. Brouwer ${ }^{1,2}$, Y. Van Sleen ${ }^{1,2} .{ }^{1}$ University Medical Center Groningen, Rheumatology and Clinical Immunology, Groningen, Netherlands; ${ }^{2}$ University Medical Center Groningen, Vasculitis Expertise Center Groningen, Groningen, Netherlands; ${ }^{3}$ Aarhus University Hospital, Department of Rheumatology, Aarhus, Denmark; ${ }^{4}$ Aarhus University Hospital, Department of Rheumatology and Department of Clinical Medicine, Aarhus, Denmark; ${ }^{5}$ University Medical Center Groningen, Department of Pathology and Medical Biology, Groningen, Netherlands

Background: Giant cell arteritis (GCA) is a granulomatous vasculitis that affects the large vessels, occurring in people over 50 years of age. GCA frequently overlaps with polymyalgia rheumatica (PMR), which affects the proximal joints in the shoulders and hips. Both GCA and PMR patients require long-term treatment with glucocorticoids (GCs). Investigation of new treatment options is required because many GCA and PMR patients experience GC-related adverse events. These include hypercholesterolemia, hypertension, diabetes mellitus, cataract, and infections.(1) Previous studies suggest that unhealthy metabolic features and a higher Body Mass Index (BMI) might be protective in the development of GCA (2). However, data are limited.

Objectives: We aimed to elaborate more-in depth on the metabolic features, BMI and prevalence of comorbidities of GCA and PMR patients at the time of diagnosis and during treatment, to characterize patients for improved treatment options.

Methods: This study included two independent cohorts: the GPS (Groningen) cohort, and the Aarhus cohort for validation of baseline data (Table 1). Patients in the GPS cohort were prospectively followed with visits at 3 months, 1, 2, and 5 years. Laboratory measurements, metabolic co-morbidities were assessed at every visit. At baseline, we assessed whether comorbidities and BMI predicted the duration of GC treatment.

Table 1. Baseline characteristics. P-values were calculated with

Mann-Whitney $U$ test and Fischer Exact test. Numbers in bold: significance between HC and GCA/PMR patients from GPS cohort. *: significance between GCA and PMR of GPS cohort. ${ }^{a}$ : significance between two cohorts.

\begin{tabular}{|c|c|c|c|c|c|}
\hline & $\begin{array}{c}\text { GCA } \\
\text { GPS } \\
\text { cohort } \\
(n=50)\end{array}$ & $\begin{array}{c}\text { PMR } \\
\text { GPS } \\
\text { cohort } \\
(n=44)\end{array}$ & $\begin{array}{c}\text { HCs } \\
\text { GPS } \\
\text { cohort } \\
(n=65)\end{array}$ & $\begin{array}{c}\text { GCA } \\
\text { Aarhus } \\
\text { cohort } \\
(n=52)\end{array}$ & $\begin{array}{c}\text { PMR } \\
\text { Aarhus } \\
\text { cohort } \\
(n=25)\end{array}$ \\
\hline Age, median & 71 & 73 & 70 & 67 & 68 \\
\hline Female, \% & 35 & 26 & 43 & 32 & 13 \\
\hline $\begin{array}{l}\text { Follow-up duration in months, } \\
\text { median }\end{array}$ & 42 & 40 & NA & NA & NA \\
\hline$B M I$, median & 24.3 & 26.6 & 25.4 & 24 & 26.4 \\
\hline Systolic BP (mmHg), median & 140 & 140 & 145 & 135 & 143 \\
\hline Diastolic BP (mmHg), median & 79.5* & 80 & 80 & 76.5 & 83 \\
\hline HbA1c (mmol/mol), median & 43 & 40 & 39 & 43 & 40 \\
\hline CRP (mg/L), median & 54 & 42 & 4 & 76 & 53 \\
\hline ESR $(\mathrm{mm} / \mathrm{h})$, median & $94^{*}$ & 57 & 9 & 77 & 51 \\
\hline Diabetes mellitus, $\%$ & 12 & 23 & 12 & 15 & 8 \\
\hline Hypercholesterolemia, \% & 22 & 14 & 17 & 15 & 24 \\
\hline Hypertension, \% & $66^{a}$ & 55 & 60 & 38 & 36 \\
\hline Cataract, \% & 14 & 16 & 34 & NA & NA \\
\hline
\end{tabular}

Results: Frequencies of metabolic features in GCA/PMR patients from the GPS cohort were not significantly different in comparison to healthy controls (HCs). Higher $\mathrm{HbA} 1 \mathrm{c}$ levels were detected in GCA patients than in HCs. Data on metabolic features from the Aarhus cohort compared well with the GPS cohort data and thus validated these findings (Table 1). Next, the effect of co-existing co-morbidities on the clinical manifestations was investigated. GCA patients with cataract had reduced CRP and ESR whereas PMR patients with cataract had a higher ESR than 
patients without cataract $(p=0,034)$. Analysis of $G C$ treatment effect on co-morbidities revealed a significant increase in prevalence of diabetes (after 3 months) and cataract (after 5 years) compared to baseline. BMI was significantly higher after one year and five years of GC treatment. PMR patients with cataract at baseline required longer treatment with $\mathrm{GCs}(\mathrm{p}=0.023)$. Presence of other metabolic features at the time of GCA or PMR diagnosis did not affect the treatment duration (Figure 1). Conclusion: Newly-diagnosed GCA and PMR patients did not appear to have a healthier metabolic profile than HCs. As expected, GC treatment resulted in the development of an unhealthier metabolic profile in GCA patients. In PMR patients, the presence of cataract at baseline was predictive for a prolonged treatment period which could be explained by higher ESR levels in PMR patients with cataract. Together, our findings emphasize the importance of novel GC sparing therapeutic agents and personalized medicine in GCA and PMR.

REFERENCES:

[1] Buttgereit F,et al. Prevention of glucocorticoid morbidity in giant cell arteritis. Rheumatol (United Kingdom). 2018.

[2]Ungprasert $P$, et al. Lower body mass index is associated with a higher risk of giant cell arteritis: A systematic review and meta-analysis. Ann Transl Med. 2015.

Disclosure of Interests: Idil Esen: None declared, Philip Therkildsen: None declared, Berit Dalsgaard Nlelsen: None declared, Anna van 't Ende: None declared, Annemieke Boots Consultant of: Grunenthal, Peter Heeringa: None declared, Ellen-Margrethe Hauge: None declared, Elisabeth Brouwer Speakers bureau: Roche, fees paid to UMCG, Yannick van Sleen: None declared DOI: 10.1136/annrheumdis-2021-eular.2425

\section{OP0068 AND TOCILIZUMAB IN TAKAYASU ARTERITIS: MULTICENTER WORLDWIDE RETROSPECTIVE STUDY OF 209 PATIENTS}

A. Mekinian ${ }^{1}$, L. Biard ${ }^{2}$, L. Dagna ${ }^{3}$, P. Jégo ${ }^{4}$, C. Salvarani ${ }^{5}$, M. Sergey ${ }^{6}$, O. Espitia ${ }^{1}$, S. Sciascia ${ }^{7}$, P. Hernan ${ }^{8}$, P. Cacoub ${ }^{1}$, O. Fain ${ }^{1}$, D. Saadoun ${ }^{9}$ on behalf of TAK FRENCH GROUP. ${ }^{1}$ Saint Antoine, Internal Medicine, Paris, France; ${ }^{2}$ Saint Antoine, SDF, Paris, France; ${ }^{3}$ Saint Antoine, QF, Paris, Italy; ${ }^{4}$ Saint Antoine, SFD, Paris, France; ${ }^{5}$ Saint Antoine, Internal Medicine, Itale, Italy; ${ }^{6}$ Saint Antoine, Internal Medicine, Moscou, Russian Federation; ${ }^{7}$ Saint Antoine, Internal Medicine, Paris, Italy; ${ }^{8}$ Saint Antoine, Internal Medicine, Paris, Spain; ${ }^{9}$ Pitie, Internal Medicine, Paris, France

Background: In this large worldwide TAK registry, we report 209 patients treated with TNF- $\alpha$ antagonists and tocilizumab aiming to compare their safety and efficacy, and determine the predictive factors of treatment response and relapse. Objectives: To assess safety and efficacy of TNF- $\alpha$ antagonists and tocilizumab in patients with Takayasu arteritis (TAK).

Methods: We conducted a retrospective multicenter study in referral centers from France, Italy, Spain, Israel, Japan, Tunisia and Russia about biological-targeted therapies in TAK during the period from January 2017 to September 2019 for the data collection.

Results: Two-hundred nine patients with TAK [median age of 29 years [7-62], and $186(89 \%)$ females] were included. They received either TNF- $\alpha$ antagonists $[n=132$ (63\%) with 172 lines; infliximab $(n=109)$, adalimumab $(n=45)$, golimumab $(n=8)$, certolizumab $(n=6)$ and etanercept $(n=5)]$, or tocilizumab $[n=77(37 \%)$ with 121 lines; intravenous and subcutaneous in 95 and 26 cases, respectively]. A complete response at 6 months was evidenced in 101/152 (66\%) on TNF- $\alpha$ antagonists and $75 / 107(70 \%)$ on tocilizumab, respectively. Age $\geq 30$ years [OR= 2.09 [1.09; 3.99]] was associated with complete response, whereas vascular signs [0.26 [0.1;0.65]], baseline prednisone $\geq 20 \mathrm{mg} /$ day [0.51 [0.28;0.93]] were negatively associated with the complete response to TNF- $\alpha$ antagonists or tocilizumab. During a median follow-up of 36 months, 103 relapses were noted. Supra-aortic branches and thoracic aorta involvements [HR $2.44(1.06 ; 5.65)$ and $3.66(1.18 ; 11.4)$, respectively], and systemic signs at baseline [HR $2.01(1.30 ; 3.11)]$ were significantly associated with relapse. The cumulative incidence of treatment discontinuation and relapse were similar in TNF $\alpha$ antagonists and tocilizumab. Fifty-eight (20\%) adverse effects occurred on biological-targeted therapies of whom $37(21 \%)$ and $21(17 \%),(p=0.4)$ on TNF- $\alpha$ antagonists and tocilizumab, respectively

Conclusion: This large multicenter study shows high efficacy of biological-targeted treatments in refractory TAK. Efficacy, relapse and drug retention rate were equivalent with TNF- $\alpha$ antagonists and tocilizumab.

Disclosure of Interests: None declared

DOI: 10.1136/annrheumdis-2021-eular.2843

\section{OP0069 THE ROLE OF POSITRON EMISSION TOMOGRAPHYI COMPUTED TOMOGRAPHY (PET/CT) IN DISEASE ACTIVITY ASSESSMENT IN PATIENTS WITH LARGE VESSEL VASCULITIS}

E. Galli ${ }^{1}$, F. Muratore ${ }^{2}$, L. Boiardi ${ }^{2}$, M. I. Casali ${ }^{3}$, A. Versari ${ }^{3}$, G. Besutti ${ }^{4}$, L. Spaggiari ${ }^{4}$, P. Mancuso ${ }^{5}$, P. Giorgi Rossi ${ }^{5}$, C. Salvarani ${ }^{1,2} .{ }^{1}$ University of
Modena and Reggio Emilia, Department of Rheumatology, Modena, Italy; ${ }^{2}$ Rheumatology Unit, Azienda USL-IRCCS di Reggio Emilia, Department of Specialistic Medicine, Reggio Emilia, Italy; ${ }^{3}$ Nuclear Medicine Unit, Azienda USL-IRCCS di Reggio Emilia, Department of Oncology and Advanced Technology, Reggio Emilia, Italy; ${ }^{4}$ Radiology Unit, Azienda USL-IRCCS di Reggio Emilia, Department of Imaging and Laboratory Medicine, Reggio Emilia, Italy; ${ }^{5}$ Epidemiology Unit, Azienda Unità Sanitaria Locale-IRCCS di Reggio Emilia, Department of Epidemiology Service, Reggio Emilia, Italy

Background: Assessment of disease activity in large vessel vasculitis (LVV) is still an unmet need. PET Vascular Activity Score (PETVAS) is a new composite score aimed at quantifying the overall inflammatory burden by adding together PET qualitative visual scores (0-3, according to Meller) in nine selected arteria regions (1). In two independent cohorts, PETVAS showed to be effective in discriminating between patients with clinically active and inactive vasculitis.

Objectives: To assess the role of PET/CT and the performance of PETVAS in differentiating between clinically active and inactive vasculitis in a single center cohort of patients with LVV.

Methods: One-hundred patients with radiographic evidence of LVV were enrolled by the Rheumatology Unit of Reggio Emilia Hospital (Italy) between June 2007 and September 2020. All subjects underwent full clinical, laboratory and imaging evaluation (including PET/CT) at baseline, annually and when a relapse was suspected. Medical records of recruited patients were retrospectively reviewed from baseline visit until 30 September 2020, last follow-up or death.

For each PET/CT test, the nuclear medicine physician's interpretation of scans (active/inactive vasculitis) was compared with disease activity clinical judgement (active disease/remission). The latter was based on comprehensive signs/symptoms assessment, laboratory and imaging (excluding PET/CT) data and was considered the reference standard.

For each PET/CT scan, PETVAS score was calculated and its performance in discriminating between patients with active and inactive disease was compared to clinical judgement.

Results: In the study period 100 LVV patients [51 giant cell arteritis (GCA), 49 Takayasu arteritis (TAK)] underwent a total of 474 PET scans. Nuclear medicine physician's interpretation of PET/CT was able to discriminate between patients in clinically active LVV ( $n$ 167) and those in clinical remission ( $n$ 307) with a sensitivity of $60 \%$ ( $95 \% \mathrm{Cl}, 51$ to $69 \%$ ) and a specificity of $80 \%(95 \% \mathrm{Cl}, 75$ to $84 \%$ ). The following sensitivity and specificity values were found in LVV subgroups: $73 \%(95 \% \mathrm{Cl}, 59$ to $84 \%)$ and $77 \%(95 \% \mathrm{Cl}, 70$ to $83 \%)$ for TAK, and $51 \%(95 \%$ $\mathrm{Cl}, 38$ to $63 \%)$ and $82 \%(95 \% \mathrm{Cl}, 76$ to $88 \%)$ for $\mathrm{GCA}$, respectively.

LVV patients with higher PETVAS scores were more frequently classified as having active disease: age and sex adjusted OR $1.15(95 \% \mathrm{Cl}, 1.11$ to 1.19$)$ $\mathrm{p}<0.0001$. Similar results were found in LVV subgroups, [age and sex adjusted OR $1.12(95 \% \mathrm{Cl}, 1.08$ to 1.17$)$ for GCA and 1.22 (95\% Cl, 1.14 to 1.31$)$ for TAK all $\mathrm{p}<0.0001]$.

The area under receiver operating characteristics (ROC) curve (AUC) of PETVAS in differentiating between clinically active and inactive LVV was $0.73(95 \%$ $\mathrm{Cl}, 0.68$ to 0.79$)$. Similar results were found in LVV subgroups, $[0.70(95 \% \mathrm{Cl}$, 0.62 to 0.78$)$ for GCA, and $0.79(95 \% \mathrm{Cl}, 0.71$ to 0.87$)$ for TAK]. A PETVAS $\geq 10$ provided $61 \%$ sensitivity and $80 \%$ specificity in differentiating between clinically active and inactive LVV $(52 \%$ sensitivity and $82 \%$ specificity in GCA subgroup and $73 \%$ sensitivity and $78 \%$ specificity in TAK subgroup).

Conclusion: In our cohort PET/CT has shown to be useful in monitoring LVV disease activity.

PETVAS seems to be a reliable tool in helping clinicians to discriminate between LVV patients with active disease and those in remission.

REFERENCES:

[1] Grayson PC, Alehashemi S, Bagheri AA, Civelek AC, Cupps TR, Kaplan MJ, Malayeri AA, Merkel PA, Novakovich E, Bluemke DA, Ahlman MA. 18 F-Fluorodeoxyglucose-Positron Emission Tomography as an Imaging Biomarker in a Prospective, Longitudinal Cohort of Patients with Large Vessel Vasculitis. Arthritis Rheumatol. 2018 Mar;70(3):439-449. doi: 10.1002/art.40379. Epub 2018 Feb 6. PMID: 29145713; PMCID: PMC5882488.

Disclosure of Interests: None declared

DOI: 10.1136/annrheumdis-2021-eular.3713

\section{OP0070 ONSET TO DIAGNOSIS TIME PREDICTS SURVIVAL RATE IN TAKAYASU ARTERITIS}

A. Popov ${ }^{1}$, I. Borodina ${ }^{2}$, L. Shardina ${ }^{3} .{ }^{1}$ Ural State Medical University, Hospital Therapy and Urgent Medical Care Service, Ekaterinburg, Russian Federation; ${ }^{2}$ Sverdlovsk Regional Clinical Hospital 1, Therapy, Yekaterinburg, Russian Federation; ${ }^{3}$ Ural State Medical University, Higher Medical Nurse and Social Education, Yekaterinburg, Russian Federation

Background: Takayasu arteritis (TA) is large vessel vasculitis. In spite of relatively high 5 to 15 years survival rate, TA affects young persons and causes major cardiovascular events, disability and preterm deaths [1]. Nowadays, though new 